\title{
A kínvallatás tilalmának megjelenése a mai kor büntetőjogában, Beccaria szellemében
}

\section{KOVÁCS ISTVÁN ${ }^{1}$}

A Dei delitti e delle pene címü könyv alapjaiban határozta meg a mai modern büntetőjog alapelveit. A könyv eredetét és szerzőségét legtöbben Beccariának tulajdonitják, de annak szerzősége körül korában és később is számos vita alakult ki. Tanulmányomban a forráskritika módszerével az „Öklök Társaságának” emlékiratait, az egyes tagok visszaemlékezését is elemzés tárgyává teszem, több magyar nyelvü forditást is megvizsgálok, amely a szerzöség körül kialakult vitát más aspektusból is megismerteti. Mindemellett a tanulmányban a könyvben tárgyalt kínvallatás módszerét történeti és jogi szempontból is bemutatom, valamint kvantitatív eljárás segítségével megvizsgálom, hogy Magyarországon e büncselekménnyel kapcsolatban milyen eljárások voltak folyamatban az elmúlt években, azoknak mik a tendenciái. Vajon ma Magyarországon a kínvallatás a hatóság egyik eszköze, vagy az emberi és alkotmányos jogok gyakorlása érvényesül, és a kötelemteljesités is törvényben meghatározott feltételek szerint alakul.

Kulcsszavak: Beccaria, kényszervallatás, büntetőjog, bűncselekmény, alapvető emberi és alkotmányos jogok

\section{The Emergence of the Prohibition of Torture in Contemporary Criminal Law in the Spirit of Beccaria}

The book "Dei delitti e delle pene" fundamentally set out the principles of modern criminal law today. Most attribute the origin and authorship of the book to Beccaria, but there have been many debates about its authorship in his day and later. In my study, I use the method of source criticism to analyse the memoirs of the "Öklök Társasága" and the recollections of individual members, I also examine several Hungarian translations, which introduces the debate around authorship from other aspects. In addition, in the study I present the method of torture discussed in the book from a historical and legal point of view, and with the help of a quantitative procedure I examine what proceedings have been going on in Hungary in connection with this

1 Adjunktus, Nemzeti Közszolgálati Egyetem Rendészettudományi Kar, e-mail: kovacs. istvan@uni-nke.hu 
crime in recent years and its tendencies. Is torture one of the means of authority in Hungary today, or is there no such restriction on the exercise of human and constitutional rights, and does the fulfilment of obligations also take place under the conditions specified by law?

Keywords: Beccaria, forced interrogation, criminal law, crime, fundamental human and constitutional rights

\section{Bevezetés}

Tanulmányomat a modern büntetőjog alapelveinek megfogalmazója, Cesare Marchese Beccaria ihlette. A publikációban górcső alá veszem, hogy a kínvallatás ellen felszólaló és annak eltörlését szorgalmazó beccariai alapeszme ma a magyar jogrendszerben, azon belül a büntető jogalkotásban és annak alkalmazásában miként is érvényesül. A tanulmányban kritikai forráselemzést, valamint a Belügyminisztérium égisze alatt működő Bủnügyi Statisztikai Rendszerből származtatott szekunder adatok elemzését hajtom végre.

Beccaria, egy gazdag nemesi család elsőszülött fiaként Észak-Olaszország legnagyobb városában, Milánóban született 1738. március 15-én. A nemesi vérvonal megkövetelte volna tőle, hogy a családi hírnév és tekintély öregbítésén munkálkodjon, azonban Beccaria naplójának személyes feljegyzései is gyakorta utaltak rá, hogy ő maga is irtózott a család mesterkélt, fojtogató légkörétől, így nem váltotta be a szülői reményeket. Kapcsolata a családjával végleg megromlott, amikor 1760-ban feleségül vette - a rangon alulinak tartott - déli származású Teresa de Blascót. Tanulmányait Pármában kezdte, majd a Pavia városában található jogi egyetemen doktorátust szerzett. A feldolgozott forrás szerint Beccaria a jogtudományban semmi vonzót nem talált, így filozófiával kezdett foglalkozni; sokat forgatta Helvétiust, d'Alembert-t, valamint Montesquieu-t is, akiknek művei, eszméi nagy hatással voltak rá. ${ }^{2}$

Ekkortájt ismerkedett meg Pietro Verrivel, aki a kor egyik leghíresebb közgazdásza volt. Többek között általa, a közvetítésével sikerült Beccariának a későbbi „Accademia dei Pugni” társaságba is bekerülnie. A társaság alapítását (1761-ben) Pietro és Alessandro Verri, valamint Luigi Lambertenghi nevéhez köthetjük. ${ }^{3}$ (Beccaria csak később lett a társaság tagja.) Tagjai a legkülönfélébb tudományterületekről érkező, felvilágosult gondolkodók voltak, akik rendszeres vitákat folytattak a politikai, a vallási és a társadalmi életről. Céljuk többek között Lombardia több évszázados szellemi elmaradottságának felzárkóztatása, valamint a despotikus uralmi rendszer erőszakosságával szembeni reformjavaslatok kidolgozása volt. ${ }^{4}$ A korban végigsöprő

2 Mucsi Emese: Egy könyv - kétszáz év távlatából. Világtörténet, 9. (1987), 1. 61-83.

3 A szerző megjegyzése: magyar fordításban „Öklök Akadémiája” vagy „Ököltársaság”.

4 Gaetano Compagnino: Gli illuministi italiani. Roma-Bari, Editori Laterza, 1982. 
felvilágosodás a társadalmi élet négy alapterületét, így a gazdaságot, az etikát, a jogot és az irodalmat érintette. Az alapítástól kezdődően számtalan monográfia és tanulmány született, amelyeket szerkesztett kötetben, az Il Caffé nevü folyóiratban tettek közzé. ${ }^{5} \mathrm{~A}$ korszakban a közfigyelem leginkább a gazdasági és jogi írásokra fókuszált, amelyek többek között Verri, ${ }^{6}$ Genovesi, ${ }^{7}$ Galiani ${ }^{8}$ és Filangieri ${ }^{9}$ tollából íródtak. Beccaria nem csak jogi témákkal kapcsolatos anyagokat publikált, ez időben született A közgazdaságtan elemei címü könyve is, amelyet csak halálát követően publikáltak. ${ }^{10}$ A társaság tagjaként mind közül a modern büntetőjog alapelveit lefektető bűnökről és büntetésekről szóló könyve ${ }^{11}$ a jogászvilág mai napig is használt egyik leghíresebb forrása. Az alkotást Venturi a 18. század egyik legjelentékenyebb könyvének nevezte. ${ }^{12}$

Számos szerzö ${ }^{13}$ a könyv indító okaként a Calas-pert ${ }^{14}$ jelöli meg, amely történeti szempontból valóban eredményezhette, hogy Beccaria felvilágosult gondolkodóként

$5 \quad$ A legenda szerint a folyóirat azért kapta az Il Caffé elnevezést, mert a társaság által tárgyalt témák a tagok fejéből egy képzeletbeli kávézóban születtek, és úgy tartották, hogy a felvilágosodás - akárcsak egy frissen pörkölt olasz kávé - felébreszti a szellemet. Marcello Maestro: Cesare Beccaria e le Origini della Riforma Penale. Milano, Editori Feltrinelli, 1977.

6 Pietro Verri: Meditazioni sull'economia politica. Milano, Nella stamperia e fonderia di G. G. Destefanis, 1771; Pietro Verri: Osservazioni sulla tortura. Milano, Milano Presso de Giuseppe Marelli, 1777.

7 Antonio Genovesi: Lezioni di commercio, o sia d'economia civile. Milano, Dalla Societa Tipografica de Classici Italiani, 1765.

8 Ferdinando Galiani: Della moneta. Napoli, Nella Stamperia Simoniana, 1751.

9 Gaetano Filangieri: Scienza della legislazione. Napoli, Nella Stamperia di Amato Cons, 1780.

10 Cesare Beccaria: Elementi di economia pubblica. Milano, Nella stamperia e fonderia di G.G Destefanis, 1804.

11 Cesare Beccaria: Dei delitti e delle pene. Livorno, Marco Coltellini, 1764.

12 Franco Venturi: Settecento Riformatore I. Da Muratori a Beccaria. Torino, Einaudi, 1969.

13 Hautzinger Zoltán: Prológus. Cesare Beccaria, a bűnmegelőzési tudomány történetének nagy gondolkodója. In: Hautzinger Zoltán (szerk.): Tanulmányok a „Határörség szerepe a bünmegelözésben" címü tudományos konferenciáról. Pécs, Magyar Hadtudományi Társaság, 2003. 7-9; Belovics Ervin (szerk.): Büntetőjog V. Általános rész. Budapest, HVG-ORAC, 2014; Cesare Beccaria: Büntett és büntetés. Ford. Sebestyén Pál - Kádár Miklós. Budapest, Akadémiai Kiadó, 1967.

14 1762. március 9-én Toulouse-ban megkínozták majd kivégezték a halálbüntetéssel sújtott Jean Calas francia állampolgárt, mert a bíróság bünösnek találta Marc Antoine Calas sérelmére elkövetett emberölés büntettében. A férfi büntetlen előéletű volt, fia pedig személyiségzavarokkal küzdött. A büntetőeljárás során - amely a bírósági eljárást jelentette - nem került elő olyan bizonyíték, amely egyértelmüen alátámasztotta volna, hogy a kereskedő fia halálát idegenkezüség okozta volna (az öngyilkosság tényét aligha lehetett kétségbe vonni), azonban a 13 főből álló bíróság tanácsa a vallási fanatizmussal átitatott közhangulat hatására, többségi szavazattal kimondta a férfi halálos ítéletét. A halálbüntetést megelőzte a kínvallatás, amely egyrészt eszközéül szolgált volna annak, hogy a férfi bevallja büneit, azaz beismerő vallomást tegyen, másrészt pedig mindez az ítélet igazolását jelentette volna. A per lezárását követően Voltaire - a híres felvilágosult filozófus - az irodalom segítségével elérte azt, hogy a kor ismert ügyvédjeinek közreműködésével újratárgyalják a pert. A megismételt eljárásnak sikerült rehabilitálnia Jean Calas-t, majd a különböző tudományos mozgalmak céljukként fogalmazták meg mindazon elvek összefoglalását és közzétételét, amelyek a felvilágosodás szellemében az inkvizíciós módszereken (embertelen, megalázó) alapuló eljárások megszüntetését és az igazságon nyugvó büntetőhatalom alapköveit lefektették. 
és jogvégzett szakemberként olyan művet alkosson, amely az akkori itáliai jogrendben hatályban levő büntető rendelkezések hiányosságait, a mai modern büntetőjog alapgondolataival teljes mértékben ellentétes rendelkezéseit mutatja be. De korántsem szabad elfeledkeznünk más történeti forrás más nézőpontból való bemutatásáról sem, amely így a mű keletkezésének teljes egészét veszi górcső alá.

Maga a szóban forgó könyv bevezetése anekdotaként tesz említést arról, hogy az Il Caffé egyik tagja - aki egyben fenntartója is volt a lapnak, nevezett Verői Sándor gróf - Beccariát mint jogképzett szakembert kérte fel arra, hogy készítsen egy olyan tudományos művet, amely az Itáliában hatályos és a büntető igazságszolgáltatás során alkalmazott büntető rendelkezéseit bemutatja, azoknak elavultságára és fogyatékosságára pedig rámutat; Beccaria pedig örömmel vállalkozott a feladat teljesítésére. Mindez megtalálható az 1797-es velencei kiadásban, ${ }^{15}$ majd ezt vette át az 1887-es ${ }^{16}$ és az 1967-es ${ }^{17}$ magyar fordított kiadás is. Mucsi, aki a mű körülményeit a rendszerváltás előtt részletes elemzés tárgyává tette, több helyen is ellentmondónak tartja a mü keletkezésének effajta körülményeit. A szerző szerint Verői Sándor gróf személye nem volt más, mint Alessandro Verri, azaz Pietro Verri testvére, aki a társaságnak csak tagja és nem vezetője volt, így azt kevésbé tudta anyagilag támogatni. Arra a szerző nem ad magyarázatot, hogy a Verri vezetéknévből hogyan lett Verői, de míg a velencei kiadás a nevet helyesen rögzíti, addig a magyar fordítás a vezetéknevet átkeresztelte. Beccaria ugyan jogképzett ember volt, de az önéletrajzi ismertetőből is jól látszik, hogy szakmáját egyáltalán nem gyakorolta, a filozófia iránt kezdett érdeklődni. Mindezt alátámasztani látszik az is, hogy a könyv nem jogi, hanem filozófiai szempontból elemzi a bűn és büntetések közötti relációt. Egy másik forrás minderről hasonlóképpen vélekedik. Beccaria megkülönböztetve a vallási, a természeti és az emberi erényt és bünt arra a következtetésre jutott, hogy csak a vallási erény és bün fogalma egy és változatlan, az emberi erény és bün fogalma relatív, az emberi viszonyokkal együtt változik. Ezeket a kategóriákat elkülönítve kell megalkotni a törvényeinket, és ilyen módon kell állást foglalni a büntetés jogosságáról és hasznosságáról is. A könyv tehát - ebben az értelmezésben - filozófiai követelmények nyomán és nem jogi következtetések alapján sürgeti a büntetőjogi viszonyok megreformálását. ${ }^{18}$ A szerző szerint több forrás is utal arra, hogy Beccariát senki sem kérte fel a mü megírására, csupán barátainak unszolására fogott annak neki. ${ }^{19}$ Mucsi tanulmányában lelhető fel hivatkozásként az a Pietro Verri naplójából származó 1765. november 1 -jei bejegyzés is, amely szerint:

15 „Aneddoto concernente l'origine del trattato Dei delitti e delle pene...” Cesare Beccaria: Dei delitti e delle pene. Venezia, Bassano, 1797.

16 Cesare Beccaria: Büntett és büntetés. Ford. Tarnai János. Budapest, Révai Leo, 1887.

17 Beccaria (1967): i. m.

18 Lamm Vanda - Peschka Vilmos (főszerk.): Jogi Lexikon. Budapest, KJK-Kerszöv, 1999.

19 Mucsi (1987): i. m. 
„A Dei delitti Beccaria gróf műve, de az ötletet én adtam neki, a gondolatok többnyire a mindennapos eszmecserék eredményei, melyek Beccaria, Alessandro, Lambertenghi és énközöttem folytak [...] én ezt ajánlottam neki, mivel úgy gondoltam, hogy egy szónoki képességekkel és élénk képzelőerővel rendelkező embernek ez pontosan megfelelne. Csakhogy ő semmit nem tudott a mi büntetőrendszerünkről. Alessandro, aki börtönfelügyelő volt, megígérte neki, hogy segíteni fog. Beccaria kis papírlapokra kezdte írni ötleteit. Mi lelkesen segítettünk, és annyit biztattuk, hogy rengeteg gondolatot összeírt [...]. Mivelhogy az anyag együtt volt, megírtam a művet, és megszerkesztettem, így jött létre a könyv". ${ }^{20}$

Alessandro 1803. április 16-i keltezésủ levelében, amelyet Pietro Verri önéletrajzi írójának küldött, nem tudta kétséget kizáróan állítani, hogy a könyvet Pietro írta volna, de bizonyos, hogy azt ő tisztázta le. Mindketten egyetértettek abban, hogy Beccaria egy, de legfeljebb kettő órát tudott foglalkozni az anyaggal mert elfáradt, így azt mindig Pietro vette gondozásba. Pietro újabb feljegyzéséből tudhatjuk azt meg, hogy a könyv eredeti példányát valóban magánál tartotta, és azt pont a szerző személyével kapcsolatosan kialakult eljárások során 1769-ben szolgáltatta vissza Beccariának. ${ }^{21}$ Pietro állítása szerint a mű 1763-1764 között született, amelyre Beccaria akként reflektál, hogy 1760-61. elején kezdett filozófiával foglalkozni, mindennek hatására pedig 1763 nyarán írta meg a könyvet egy vidéki kis farmon, ahol munkát vállalt. Mindezzel szemben Alessandro csak két hónapot említ.

A könyv végül 1764-ben jelent meg, de alig száradt meg a festék a lapokon, máris kialakultak a szerző személyéről szóló viták, amelyeket tovább nehezített, hogy időközben egy teljesen anonim szerzőjü példány is megjelent, majd több fordításban is közölték azokat.

A forráskritika bármelyik verzióját is vesszük alapul, a Dei delitti e delle pene címủ alkotás a halálbüntetés, a kegyetlen és embertelen bánásmód, valamint a kínvallatás eltörlése mellett lépett fel, amely a tortúrák helyébe a modern büntetőjog olyan eszméit helyezte, mint a nullum crimen sine lege, ${ }^{22}$ valamint a nulla poena sine lege elve. ${ }^{23}$

Tanulmányomban a kínvallatás intézményével foglalkozom, amelyet az adott kor történeti szempontjából Beccaria és a felvilágosult szerzők alkotásain keresztül adaptálok, majd mindezt a hatályos magyar büntetőjogi szabályozás általános és különös részében, végül a büntetőeljárások gyakorlatában szemléltetem.

20 Mucsi (1987): i. m. 70.

21 Mucsi (1987): i. m. 71; A szerző megjegyzése: lásd még az eredeti forrásokat Luigi Firpo: Edizione Nazionale delle Opere di Cesare Beccaria. Milano, Mediobanca, 1984. 217-224.

22 Azaz „nincs bủncselekmény törvény nélkül”. Ha büntető jogszabály valamely cselekményt nem nyilvánítja büntetendőnek, akkor azt nem lehet büncselekményként kezelni. Csak olyan magatartás miatt állapítható meg valakinek a büntetőjogi felelőssége, ha a cselekmény elkövetésekor (annak időpontjában) az adott magatartást a törvény büntetni rendelte és bủncselekménynek nyilvánította.

23 Azaz „nincs büntetés törvény nélkül”. A bűncselekmény elkövetőjére csak olyan büntetés szabható ki, amelyet a büntető jogszabály lehetővé tesz. 


\section{A kínvallatás}

A kínvallatás, csakúgy, mint a bün megjelenése, csaknem egyidős a társadalommal. Minden egyes történeti korszakból találunk arra példát, hogy a hatalommal rendelkező emberek a hatalmuk és befolyásuk alatt álló személyeket miként és milyen módszerekkel kínozták.

Az ókori igazságszolgáltatásban a rabszolgákkal szemben gyakorta alkalmaztak kínvallatást. Görögországban ugyanis az a felfogás uralkodott, miszerint „a beszélő szerszám" csak akkor vall őszintén, ha az öntudatlanság küszöbére kínozzák, hiszen csak a szenvedés adhat meggyőző erőt egy rabszolga szavainak. ${ }^{24}$ Ahogy azt maga Beccaria is megjegyzi:

„Ez a biztos módszer az erőteljes gonoszok felmentésére $\mathrm{s}$ a gyönge ártatlanok elítélésére. Îme, végzetes hátrányai az igazság e feltételezett kritériumának, mely valójában egy kannibálhoz méltó kritérium, s melyet a rómaiak, a barbárok ők is és nem is egy szentpontból, csak rabszolgáknak tartottak fenn..." ${ }^{25}$

A középkorban - leginkább az európai büntetőbíráskodás joggyakorlatában - az eretnekek és a boszorkányok ellen folytatott eljárásokban az egyházi bíróságok alkalmaztak kínzást és kényszerítést, azért, hogy a terheltektől a beismerő vallomást megszerezzék.

Az egyház nem feltétlen helyezkedett azonos álláspontra. 866-ban I. Miklós pápa világossá tette az egyház álláspontját a vallatási módszerekkel kapcsolatosan, amelyet Borisz bolgár herceghez írt. ${ }^{26}$ Mindebben kifejtette, hogy a vallomásnak nem eröszakkal kikényszerítettnek, hanem őszintének kell lennie. A pápa morális kérdéseket fejteget, amikor a kínvallatás sikertelensége kapcsán a becsületen ejtett szégyenfolttal példálózik; majd felteszi a kérdést, hogy az-e az igazi bűnös, aki ártatlanként már a vallatásnak erején felül nem képes ellenállni és bünösnek vallja magát, vagy az, aki erőszakkal csikart ki egy ártatlanból hamis vallomást? IV. Ince pápa - aki a bolognai egyetem tanára és a kánonjog egyik kiemelkedő alakja volt - 1252-ben a kínvallatást az igazság felderítésére alkalmas és minden jogalappal rendelkező módszernek nyilvánította. ${ }^{27}$

Ahogy mindezzel összefüggésben azt Mezey is közzéteszi: a tortúra olyan ősi jelenségként értelmezhető, amely a hatalom birtokosainak az igazság- vagy a jogszolgáltatás érdekében igénybe vett eszköztárát jelenti. A hủbéri rendszerre épülő közép-

24 Gyöngy Réka: A kényszervallatás tényállásának értelmezéséhez. Debreceni Jogi Mühely, 9. (2012), 3. 86-95.

25 Cesare Beccaria: A bünökröl és a büntetésekröl. Ford. Madarász Imre, Budapest, Eötvös József Könyvkiadó, 1998. 31.

26 Takács Andrea: Brian Innes: A kínzás és kínvallatás története - Könyvismertetés. Belügyi Szemle, 49. (2011), 11. 123-128.

27 Nagy Sándor: Kínvallatás a hajdúvárosok és a hajdúkerületi törvényszék előtt indított bűnügyekben. A Hajdú-Bihar Megyei Levéltár Évkönyve, (1997), 24. 25. 
kori Európára az őskor és ókor előzményei nagy hatást gyakoroltak, de az inkvizíció alapját jelentő gyakorlat egészen különleges helyet biztosított a kínvallatás és a kínzás jogintézményének a büntető igazságszolgáltatásban. ${ }^{28}$

A jog szempontjából a Magyar Jogi Lexikon értelmezésében a „kínvallatás a bűnvádi eljárásban a terheltnek, esetleg a tanúnak psyhikai vagy lélektani kényszer segélyével vallomásra bírását jelenti”. ${ }^{29}$ A Magyar Katolikus Lexikon ehhez képest kínvallatás alatt (latinul: quaestio, tortura) a beismerő vallomás kikényszerítésére alkalmazott, testi, lelki fájdalmat (vagy mindkettőt) okozó módszert érti. ${ }^{30}$ Bakonyi doktori értekezésében olvasott logikai és nyelvtani értelmezés szerint a kínvallatás nem büntetés volt, nem is bizonyítási eszköz. A bírák nem törekedtek a vallatott ember halálára, sőt a cél kimondottan a beismerő vallomás mint legfőbb bizonyíték megszerzése volt. Amíg a Magyar Jogi Lexikon a kínvallatás passzív alanyának tekinti („esetlegesen”) a tanút is, addig a Magyar Katolikus Lexikon „csupán” a terhelttel szembeni alkalmazhatóságot tartja kínvallatásnak, mégpedig a beismerő vallomás kikényszerítése céljából. ${ }^{31}$ Beccaria korában a kínvallatás a vádlott ellen irányult.

„A nemzetek legnagyobb részénél a szokás által szentesített kegyetlenség a vádlott kínvallatása, míg a per alakul, vagy azért, hogy egy bủntett bevallására kényszerítsék, vagy az ellentmondások miatt, amelyekbe keveredik, vagy a büntársak felderítése céljából, vagy valami nem tudom milyen metafizikus és érthetetlen becstelenségtől való megtisztítás végett, vagy végül más bűnök miatt, amelyekbe bünös lehetne, de amelyekkel nem vádolják."32

E kérdéskörben éppúgy alkalmazható volt a kínvallatás a vallomás megszerzése, a bűntársak felderítése, szakrális és koholt vagy olyan bűncselekmények elkövetése céljából, amelyeket a terhelttel szemben előzetesen a vád nem tartalmazott.

Egy másik fordításban:

„Akaratunk cselekményei mindig a forrásukat képező érzéki benyomások erejétől függnek; az ember érzékenysége pedig korlátolt. Azért a fájdalom hatása oly fokot érhet el, hogy az egész akaratot lefoglalván, a kínzottnak nem enged más választást, minthogy a szenvedéstől a pillanatnyi körülmények között kinálkozó legrövidebb úton meneküljön [...] Vajon igazságos-e a tortúra és igazak-e az eszközei? Alkalmasak-e arra, hogy elérjék a jog által kitűzött célt? A gyanúsított kínvallatása azelőtt, hogy elkészül ellene a vádirat, a nemzetek többsége által

28 Mezey Barna: Kínzás, kínszenvedés, kivégzés. Rubicon, 17. (2006), 7. 22.

29 Márkus Dezső: Magyar Jogi Lexikon. Budapest, Pallas Irodalmi és Nyomdai Részvénytársaság, 1907. 797.

30 Diós István - Viczián János (szerk.): Magyar Katolikus Lexikon. Budapest, Szent István Társulat, 1993.

31 Bakonyi Mária: A beismerö vallomás fonákja és színe - a kényszertól a konszenzusig. Doktori értekezés. Pécs, Pécsi Tudományegyetem Állam- és Jogtudományi Kar Doktori Iskola, 2019.

32 Beccaria (1998): i. m. 31. 
hosszú évek alatt szentesített kegyetlenség. A tortúra célja, hogy a gyanúsítottat rávegye a vallomástételre, az ellentmondó tényállítások tisztázására, a tettestársak kilétének felfedésére, de célja a megbecstelenítés és megalázás, valamint az is, hogy olyan cselekmények elkövetését is beismerje, amelyekkel egyelőre nem vádolják." ${ }^{33}$

Beccaria legmerészebb elvi újítása az volt, hogy elutasította a korábbi büntetőjogot uraló abszolút elméleteket és az engesztelés (expiatio) tanát. A vallási alapokra támaszkodó felfogást gyökerében támadta, a vallási fogalmakat számüzte elméletéből. Álláspontja szerint az erkölcsi cselekményeknek, éppen úgy, mint a természetieknek, elhatárolt körük van, és ahogyan a természetieket, úgy ezeket is többféleképpen korlátozza az idő és a tér. Erre az eredményre kellett jutnia, amikor arányt keresett a büntetés és a bűnhődés között, amikor a büntetés enyheségét követelte, és a bűnkutatás korlátozását kívánta. A kor öröklött büntetéstani felfogása az engesztelésre épült. Ennek célja Istennek az ember belső rosszaságért való kibékítése volt, amelyet a bűnös minél szigorúbb megbüntetése útján lehetett elérni. Ebből eredt az a felfogás, hogy nincs olyan testi kín, amely súlyát tekintve a belső gonoszsággal felérne, és nincs olyan eszköz, amit a bünösség kiderítésére ne lehetne alkalmazni. Az anyagi jogban ez a felfogás vezetett a kegyetlen büntetésekhez, különösen a minősített halálbüntetéshez, az eljárásban ez a nézet legitimálta az inkvizíciót és a kínvallatást. ${ }^{34}$ Beccaria szerint a középkor büntetési rendszere hibás elvi alapra épült. A büntetések kegyetlensége, a kínvallatás alkalmazása, a szentségtörés miatti brutális szankciók a vallási és a társadalmi szférák összezavarásának következményei. Beccaria kiváló jogászi logikával választotta el egymástól a bủnt és a bűncselekményt, az utóbbit a társadalmi rend elleni agressziónak nevezte, és arra az okozott kárral arányos büntetést szánt:

„Ha összezavarunk lényegüknél fogva különböző alapelveket - állítja a Bevezetésben -, semmi remény arra, hogy helyesen gondolkodunk politikai dolgokról. A teológusok feladata megállapítani a helyes és helytelen határvonalát annak kapcsán, hogy egy cselekedet belsőleg jó-e vagy gonosz; a politikában a helyes és helytelen kapcsolatának meghatározása - vagyis azé, hogy mi hasznos és mi káros a társadalomnak - a publicista feladata." ${ }^{35}$

Beccaria ezen az elvi alapon tagadta a kínvallatás jogosságát is. A fájdalom nem lehet az igazság kritériuma, s aki ennek az ellenkezőjét hiszi - érvel -, úgy viselkedik, mintha kannibál vagy barbár lenne (még ha ő maga római is). Beccaria rámutatott, hogy

33 Roland Mortier: Az európai felvilágosodás fényei és árnyai. Budapest, Gondolat, 1984. 17.

34 Cesare Beccaria: $A$ bünökról és a büntetésekröl. Ford. Madarász Imre, Budapest, ELTE Államés Jogtudományi Kar Demokratikus Diákuniója; Országos Pedagógiai Könyvtár és Múzeum, 1989; Stipta István: Cesare Beccaria Bűntett és büntetés címủ művének recepciója Magyarországon. Jogtörténeti Szemle, (2019), 3-4. 10-16. 
„a gonoszság kiűzésének” vallási és mitikus igényével és ennek büntetőjogi támogatásával egy vallási eredetủ fogalom uralta el a polgári törvényeket. A szent és a profán, a vallási és a laikus elem összezavarását helyteleníti a bíróság előtt kötelezően teendő eskü intézményében is.

„Miért kell az embert olyan szörnyü választás elé állítani, hogy vagy Istent sérti meg, vagy a maga romlásához nyújt segéd-kezet? Amikor a törvény megköveteli az esküt, arra kényszerít, hogy rossz keresztények vagy mártírok legyünk." ${ }^{36}$

A tanulmányban is sokszor említésre kerül, hogy a jogászvilág, különösen a büntető jogtudomány Beccariát tekinti a modern büntetőjog emberi és alkotmányos jogokon alapuló alapelvei kimunkálójának. Nem szabad viszont elfeledkeznünk arról, hogy a kínvallatás ellen nemcsak Olaszországban, hanem Európa más államaiban is felszólaltak. Sonnensfels 1775-ben írja meg az Ueber die Abschaffung der Tortur ${ }^{37}$ című kínvallatások ellen felszólaló munkáját, Voltaire pedig a Prix de la Justice et de l'Humanité és Commentaire sur le livre des délits et des peines ${ }^{38}$ címen az egyházi bíróságok ítélkezési gyakorlatában előforduló túlkapásokból készít monográfiát. A fenti művek eredményeként maga Mária Terézia, illetve jogutódja II. József is számos tartományban eltörli a kínvallatás alkalmazását, azonban a milánói Szenátus a nyomásnak nem engedett. Ekkor kérték fel Pietro Verrit, hogy foglaljon állást e kérdéskörben. ${ }^{39}$ Pietro a Szenátus és az uralkodó vitájában nem kívánt állást foglalni, ezért a művet saját elhatározásból nem publikálta, az végül Észrevételek a kínvallatásról címmel, önálló értekezésként csupán halálát követően jelent meg. ${ }^{40} \mathrm{~A}$ könyv két nagyobb fejezetre osztható, amely egyrészt a Milánóban az 1600-as években végigsöprő pestisjárvány alatt lefolytatott büntetőeljárások és a kínvallatások szerepét, a megélt élményeket, azok hitelességét kommentálja; másrészt pedig a tortúra mint eljárási eszköz történetét mutatja be, majd annak elméleti jellegéből adódóan eltörlését szorgalmazza.

„Egyértelműen bizonyítottnak tünik, hogy a tortúra cseppet sem alkalmas eszköz az igazság felderítésére, sokkal inkább arra, hogy mind a bünös, mind az ártatlan bünösnek vallják magukat, következésképpen az igazságot elmossa, semhogy napvilágra hozná." ${ }^{11}$

36 Mortier (1984): i. m. 16-17.

37 Joseph von Sonnenfels: Ueber die Abschaffung der Tortur. Zürich, Orell, Gessner, Füessling und Company, 1775.

38 François-Marie Arouet Voltaire: Prix de la Justice et de l'Humanité és Commentaire sur le livre des délits et des peines. Berne, Gazette de Berne, 1777; Francois-Marie Arouet Voltaire: Commentaire sur le livre des delits et des peines. Berne, Gazette de Berne, 1766.

39 Galicz Kamilla: A felvilágosodás elfeledett polihisztora: Pietro Verri. Studia Iuvenum Iusperitorum, (2018), 9. 43-57.

40 Verri (1777): i. m.

41 Idézi Galicz (2018): i. m. 55. 
Összességében elmondható, hogy korában nemcsak Beccaria, hanem számos más felvilágosult filozófus, jogász és társadalomtudós is prioritásként kezelte a bűncselekmények felderítéséhez, valamint a büntetőeljárások során alkalmazott eszközök és módszerek törvényes, jogszerủ és szakszerű alkalmazásához füződő alapelveket. A kínzás mint módszer teljes egészében alkalmatlan volt arra, hogy a korábban megtörtént és az eljárás által a múltban megtörtént magatartást valósághűen, torzítástól mentesen rekonstruálni tudja.

\section{Kényszervallatás mint büncselekmény}

A kényszervallatás történelmi és jogtörténeti előzményeitől a tanulmány eltekint, a vizsgálat tárgyát kizárólag a hatályos Büntető Törvénykönyv rendelkezései képezik.

Az Országgyülés szem elött tartva a nemzetközi jogi és európai uniós kötelezettségeinket, az ember sérthetetlen és elidegeníthetetlen alapvető jogainak, továbbá az ország függetlenségének, területi épségének, gazdaságának, valamint a nemzeti vagyonnak a védelme érdekében, valamint azért, hogy az állam kizárólagos büntető hatalmát érvényesíteni tudja, megalkotta a 2012. évi C. törvényt, a Büntető Törvénykönyvet. ${ }^{42}$

A törvény az első fejezetet megelőző bevezetésben is már leszögezi, hogy az alkotmányos és emberi jogok védelme az állam elsőrendű kötelezettsége, amelyet a nemzetközi joganyag akceptálásával a hazai joganyag részévé tesz, annak védelmét az ultima ratio elvén keresztül megteremti.

Több nemzetközi szerződés is foglalkozik az ember elidegeníthetetlen jogaival, amelyeket a kínzás tilalmának alapjául szolgáló emberi méltóság és az élethez való abszolút jogok teremtenek meg. Ilyen például a nemzetközi humanitárius jog, ${ }^{43}$ a nemzetközi szinten ius cogens szabályt alkotó emberiesség elleni vagy háborús büncselekmények, valamint - talán az egyik legismertebb - az Emberi Jogok Egyetemes Nyilatkozata is. A nemzetközi joganyag 5. cikke szerint: „Senkit sem lehet kínzásnak, avagy kegyetlen, embertelen vagy lealacsonyító büntetésnek vagy bánásmódnak alávetni." ${ }^{44}$ Ugyanez igaz az 1984-ben elfogadott ENSZ Egyezményre is, amely az Egyezmény a kínzás és más kegyetlen, embertelen vagy megalázó bánásmód vagy büntetés ellen nevet viseli. Az Egyezmény 1. cikke nemcsak a kínzás fogalmát, hanem abból adódóan egy nemzetközi büntető törvényi tényállás objektív elemeit is megfogalmazza.

„Minden olyan cselekmény, amelyet szándékosan, éles testi vagy lelki fájdalom vagy szenvedés kiváltása céljából alkalmaznak valakivel szemben, hogy tőle, illetőleg harmadik személytől értesüléseket vagy vallomást csikarjanak ki; vagy hogy olyan cselekmény miatt büntessék, amelyet ő vagy harmadik személy követett el;

42 2012. évi C. törvény a Büntető Törvénykönyvről.

43 A szerző megjegyzése: a hatályos nemzetközi humanitárius jog alapját az 1949-es négy genfi egyezmény, valamint a hozzá tartozó, később - 1977-ben - született jegyzőkönyvek képezik. United Nations: A Universal Declaration of Human Rights (1948. december 10.). 
illetőleg amelynek elkövetésével őt vagy harmadik személyt gyanúsítanak, hogy megfélemlítsék, vagy nyomást gyakoroljanak rá; illetőleg hogy harmadik személyt félemlítsenek meg, vagy hogy harmadik személyre gyakoroljanak nyomást; valamint bármilyen megkülönböztetési formára alapított más okból alkalmaznak, ha az ilyen fájdalmat vagy szenvedést közfeladatot ellátó személy vagy hivatalos minőségben eljáró bármely más személy vagy ilyen személy kifejezett vagy hallgatólagos ösztönzésére vagy ennek hozzájárulásával bárki más okozza." ${ }^{45}$

Magyarország Alaptörvényének III. cikke kimondja, hogy: „Senkit nem lehet kínzásnak, embertelen, megalázó bánásmódnak vagy büntetésnek alávetni [...]."46 Tekintettel arra, hogy a jogforrás tetején elhelyezkedő Alaptörvényből származtatjuk a hierarchia többi szintjén elhelyezkedő további jogi normákat - és az Alaptörvény Q cikke kötelezettséget vállal a nemzetközi jog adaptálására -, így a kínzás tilalmával kapcsolatban a Büntető Törvénykönyvnek is e cikk mentén kellett születnie, az abban foglaltaknak érvényesülnie.

A Büntető Törvénykönyv 303. \$-a rendelkezik a kényszervallatás törvényi tényállásának megalkotásáról.

„Az (1) bekezdés szerint az a hivatalos személy, aki annak érdekében, hogy más vallomást vagy nyilatkozatot tegyen, illetve ne tegyen, erőszakot, fenyegetést, vagy más hasonló módszert alkalmaz, bűntett miatt egy évtől öt évig terjedő szabadságvesztéssel büntetendő. A (2) bekezdés szerint a büntetés két évtől nyolc évig terjedő szabadságvesztés, ha az (1) bekezdésben meghatározott büncselekményt csoportosan követik el. A (3) bekezdés szerint, aki a kényszervallatásra irányuló előkészületet követ el, vétség miatt két évig terjedő szabadságvesztéssel büntetendő. A (4) bekezdés szerint korlátlanul enyhíthető annak a büntetése, aki (2) bekezdésben meghatározott büncselekmény elkövetésének körülményeit a vádemelés előtt a hatóság előtt feltárja." ${ }^{47}$

A büncselekmény jogi tárgya egyrészt a hivatali apparátus törvényes bizonyítékszerző tevékenységébe, törvényes működésébe vetett bizalom, másrészt pedig a hivatalos személy előtti eljárásban, az abban részt vevők emberi méltósága, az eljárás során gyakorolható akaratszabadsága. Az elkövetési tárgy a kihallgatásra, nyilatkozat tételére kötelezett személy, azaz más, mint passzív alany. Az elkövetési magatartást a jogalkotó erőszakban, fenyegetésben és más hasonló módszer alkalmazásában jelöli meg. A bủncselekmény alanya speciális, azaz csak hivatalos személy követheti el a büncselekményt. Gondatlan elkövetése az alakzatnak nincs, azt csak szándékosan és célzattal lehet elkövetni, amely a vallomás vagy nyilatkozat tételének, tevékenységének, ille-

45 UNHR: Convention against Torture and Other Cruel, Inhuman or Degrading Treatment or Punishment (1984. december 10.).

46 Magyarország Alaptörvénye (2011. április 25.).

47 2012. évi C. törvény. 
tőleg nem tevésének felel meg. ${ }^{48}$ A csoportos elkövetés minősítő körülmény, valamint a bűncselekmény előkészülete is büntetendő. További megjegyzés a bűncselekmény megvalósulásához, hogy azt kizárólag hivatalos személy követheti el, és csak akkor, ha a hivatalos személy az eljárásban jogosult arra, hogy felhívjon más személyt vallomás vagy nyilatkozat tételére, nem tételére. Azért, hogy a személy vallomást vagy nyilatkozatot tegyen, vagy ne tegyen, szükséges, hogy a hivatalos személy az eljárása során erőszakot, fenyegetést vagy más hasonló módszert alkalmazzon. A cselekmény célja, hogy a hivatalos személy mást - akaratával ellentétes módon - vallomás vagy nyilatkozat tételére, vagy nem tételére késztesse.

Ezzel összefüggésben kell szót ejtenünk a büntetőeljárásról szóló törvény rendelkezéseiről is. A Be. 167. $\mathbb{S}(5)$ bekezdése kimondja, hogy

„nem értékelhető bizonyítékként az olyan bizonyítási eszközből származó tény, amelyet a bíróság, az ügyészség, a nyomozó hatóság, illetve a (2) bekezdésben meghatározott hatóság büncselekmény útján, más tiltott módon vagy a résztvevők büntetőeljárási jogainak lényeges sérelmével szerzett meg [...]”."

A Be. 186. $\mathbb{S}(3)$ bekezdésének $a$ ) -c) pontja szerint „a terheltnek nem tehető fel olyan kérdés, amely a választ magában foglalja vagy a feleletre útmutatást tartalmaz, a törvénnyel össze nem egyeztethető ígéretet tartalmaz, vagy valótlan tény állítását foglalja magában."50 Mindezzel pedig az alkalmazott büntetőeljárás szintén megteremti a kényszervallatás tilalmát.

Az elkövetkezendőkben vizsgáljuk meg, hogy vajon a Beccaria korától már centrumban szereplő, és a jogfejlődésben a nemzetközi és a hazai jog hatályaként a kínzással összefüggésben megalkotott törvényi tényállás, a kényszervallatás miként és milyen arányban van jelen.

\section{Bünügyi Statisztikai Rendszer - adatelemzés és a minta}

A Bűnügyi Statisztikai Rendszer az interneten közzétett, a Belügyminisztérium égisze alá tartozó, a minisztérium által müködtetett online statisztikai rendszer. ${ }^{51}$ A Konasoft által fejlesztett struktúra lehetővé teszi a nyilvánosság számára, hogy egy külső rendszeren keresztül a magyar rendvédelmi szervek által lefolytatott eljárások összességéből és azok adataiból hiteles információkat kapjon. A Belügyminisztérium Statisztikai Osztálya az adatokat folyamatosan frissíti, amely a honlapon elérhető információk szerint az Országos Rendőr-főkapitányság, a Nemzeti Adó- és Vámhivatal, valamint az Ügyészség által közzétett adatokat összesíti. 00-val kezdődő és 05-el végződő számkombinációs osztályozásból az érdeklődők a büntetőeljárások, a bűncse-

48 Papp Orsolya: Jogi-és közigazgatási ismeretek. II. Budapest, MRSZKI, 2016.

49 2017. évi XC. törvény a büntetőeljárásról.

50 2017. évi XC. törvény.

51 Bűnügyi Statisztikai Rendszer. Forrás: https://bsr.bm.hu/Document 
lekmények, a sértettek, az elkövetők és bünelkövetők, a kárra és a szabálysértésekre vonatkozó adathalmazokból válogathatnak és vizsgálódhatnak. Amennyiben egy kategóriát közelebbről is megvizsgálna valaki, a honlap egy újabb felülete könnyedén kezelhető Excel-formátumban biztosítja az adatok megismerhetőségét, amely akár napjainkra vagy akár évekre, de legkorábban 2013-ra visszamenően is tartalmaz adatokat.

A kutatással kapcsolatban megjegyzendő viszont, hogy a Bünügyi Statisztikai Rendszer is csak szekunder forrásként értelmezhető, hiszen a primer adatokat a rendvédelmi szervek, valamint az ügyészség szolgáltatja. A matematikai statisztikapróbákat tehát származtatott statisztikai adatokon tesztelem, az eredmények pedig a származtatott adatok értelmezéseiként reprezentálódnak, képezik a minta teljes egészét. A mintáról elmondható továbbá, hogy 5 év intervallum nagyságában értelmezendők, az időszakok terminológiailag fedik egymást. (Értem itt ez alatt, hogy amennyiben 2020. év első negyedévének adatai állnak rendelkezésre, az csak azon évek ugyanazon idősíkjában szereplő értékekkel vethetők össze.) Mindezek egyrészt az összes regisztrált büntetőeljárást, bűnelkövetőt, sértettet, azok település és életkor szerinti eloszlását, másrészt pedig ugyanilyen metodológia szerint a kényszervallatás büncselekmény eljárásait, sértettjeit, elkövetőit is tartalmazták.

\subsection{Az adatok elemzése}

Az első grafikonon a kényszervallatás büncselekmény 2013-2018. évi földrajzi elhelyezkedésének adatait látjuk (1. ábra). A legtöbb esetet ( $8 \mathrm{db})$ Somogy megyében követték el, amelytől nem sokkal marad el a főváros $(6 \mathrm{db})$ és Pest megye ( $5 \mathrm{db})$ sem. A legkevesebb és regisztrált elkövetés Nógrád, Szabolcs-Szatmár-Bereg, Békés és Veszprém megyében történt (1-1 db). A maximumérték így 8 büncselekménnyel Somogy megyét, míg a minimumérték a legkevesebb bủncselekménnyel regisztrált megyéket jelentette.

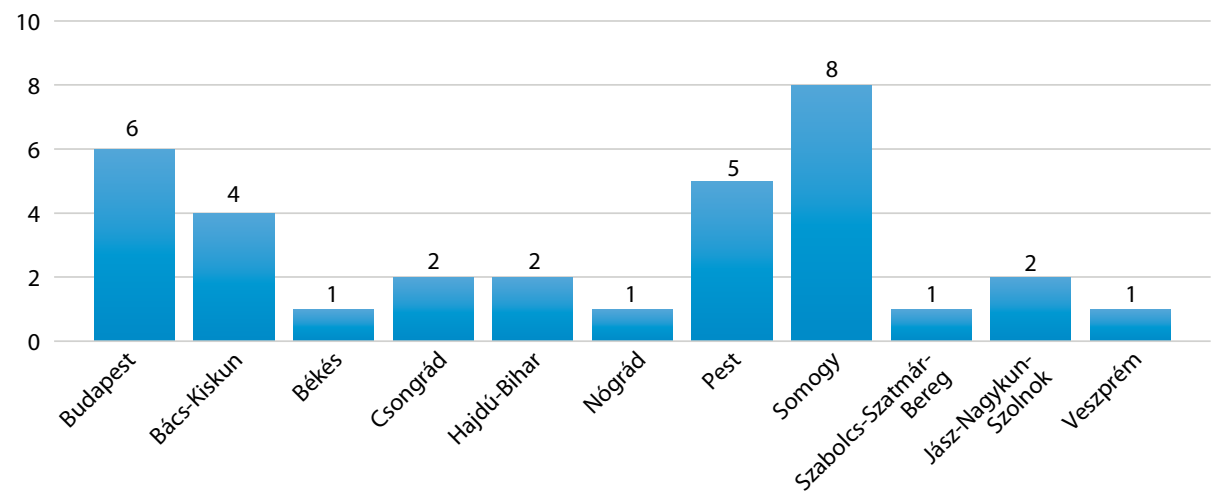

1. ábra: A kényszervallatás büntett 2013-2018. évben, megyei bontásban

Forrás: BSR alapján a szerzö szerkesztése 
A 2. ábrán a sértettek életkori ismérveivel ismerkedhetünk meg. A legtöbb esetben a bűncselekmény sértettje felnőtt életkorú (azaz 25-59 év közötti) személy volt, ami 17 büncselekményt jelentett. 9 esetben fiatalkorú (14-17 év közötti) személy volt a hatóság áldozata. A fiatal felnőttek között (18-24 év közötti) 1 áldozatról van tudomásunk. Az időskorúak között (60 év felett) 2, míg a gyermekkorúak között (0-13 év) 1 áldozat is a bűncselekmény sértettjévé vált. A maximumérték a felnőttkorúaknál, míg a minimum az idős- és gyermekkorú személyeknél tetőzött.

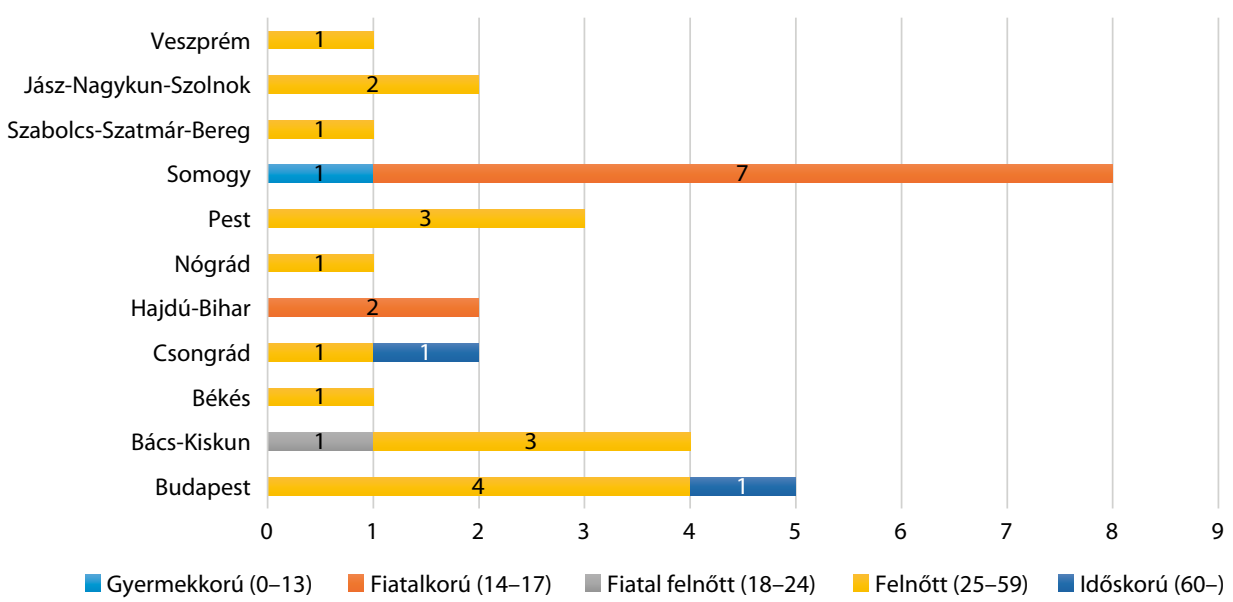

2. ábra: A kényszervallatás büntett sértettjei 2013-2018. évben

Forrás: BSR alapján a szerző szerkesztése

A harmadik ábrán az elkövetők életkorát, valamint beosztási kategóriáit láthatjuk. A büncselekmény elkövetői a felnőtt korcsoportba tartoztak (25 és 59 év között), amelyből 7 fő tiszthelyettes és mindösszesen 1 fötiszt volt. A tiszthelyettesek mind rendőr-szakközépiskolát, az egyetlen tiszt pedig föiskolát végzett. 2013-ban 2 esetet, 2014-ben és 2017-ben 3-3 esetet regisztráltak. Mindez évente átlagosan 2 bủncselekményi elkövetést jelent. A maximumérték 7, a minimum pedig 1 esetet jelentett. Az ábrához megjegyzésként szeretném hozzáfüzni, hogy az elkövetők száma nem feltétlenül egyezik meg a regisztrált bűncselekményi értékekkel, hiszen egy adott bűncselekmény több személy sérelmére is elkövethető, így a rendbeliség aránya változik.

A negyedik ábrán az elkövetés eszközét vettem górcső alá. A kényszer, fenyegetés, valamint a más eszköz mint a törvényi tényállás eszközei a legkülönfélébb eszközökkel valósultak meg. A maximumértéket $(15 \mathrm{db})$ az élet kioltására alkalmas eszközzel való elkövetés jellemezte, míg a minimumértéket $(1 \mathrm{db})$ a rendőrbot alkalmazása jelentette. A mediánértéket az eszköz nélküli elkövetés jelentette, amely 10 esetet ölel fel. 


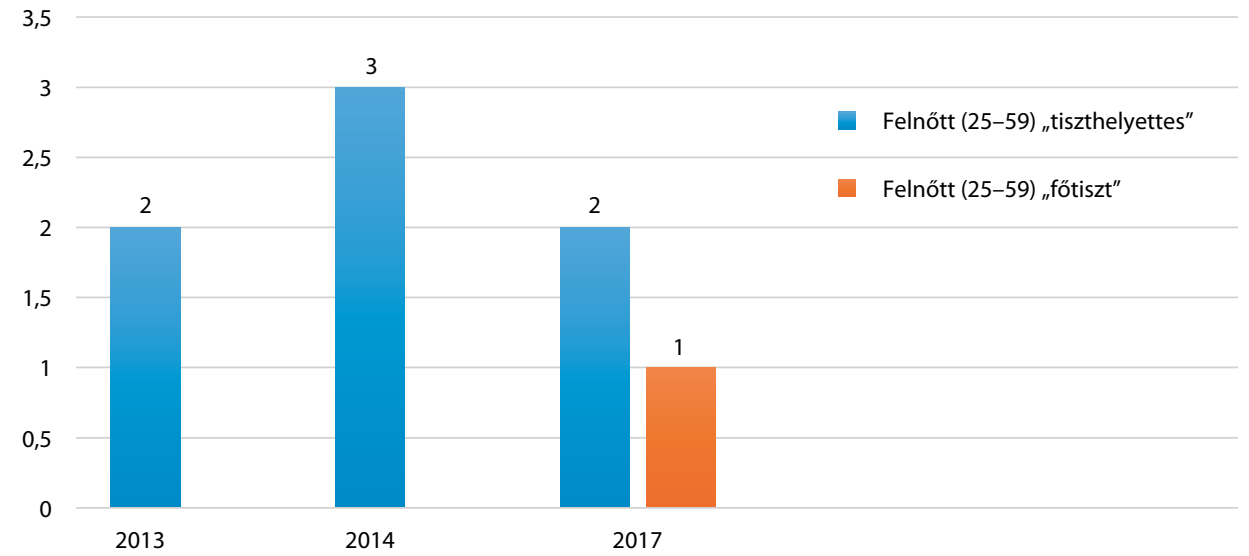

3. ábra: A kényszervallatás büntett elkövetői 2013-2018. évben

Forrás: BSR alapján a szerzö szerkesztése

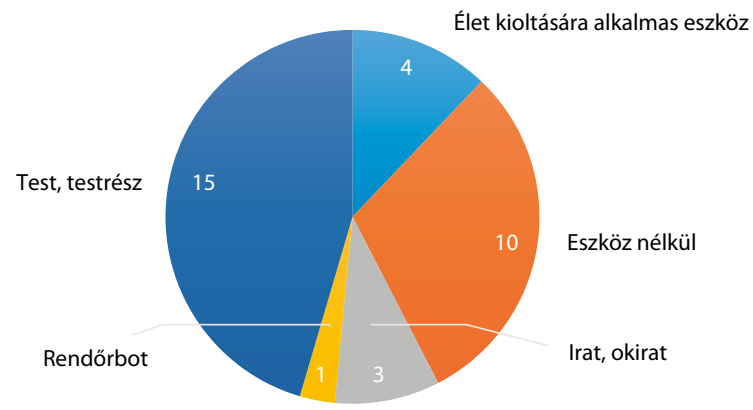

4. ábra: A kényszervallatás büntett eszközei 2013-2018. évben

Forrás: BSR alapján a szerzö szerkesztése

\section{Az eredmények értelmezése, következtetések, javaslatok}

A vizsgált időszakban az összes hivatali büncselekményhez viszonyítva a kényszervallatás bủncselekményének megvalósulása mindösszesen 6\%-ot jelentett (összes hivatali büncselekmény $474 \mathrm{db}$ vs. kényszervallatás büncselekmény $33 \mathrm{db}$ ). Kategorikusan nem jelenthető ki, hogy a 21. században alkalmazott jogrendszer teljes mértékben száműzni tudta volna a kínvallatással kapcsolatos eljárások végrehajtását. Igaz, hogy a vizsgált időszakban ez évente átlagosan nem több mint két eljárást jelentett, ami elenyésző a hivatali büncselekmények teljes számához viszonyítva, de azok a hatósági eljárásokban még köztünk élnek (kényszervallatás átlag $2 \mathrm{db}$ ). Mindehhez a hivatalos személyek a legkülönfélébb eszközöket választják, amely az élet kioltására alkalmas eszközöktől egészen a rendőrök által a törvényi felhatalmazás alapjául szolgáló kényszerítő eszközökig terjednek (élet kioltására alkalmas eszköz 15 db vs. 
rendőrbot $1 \mathrm{db}$ ). Némileg differenciált az elkövetők beosztása, hiszen mindösszesen 1 tiszt és több mint 7 tiszthelyettes követett el büncselekményt (tiszthelyettes $7 \mathrm{db}$ vs. tiszt $1 \mathrm{db}$ ). A sértettekről elmondható, hogy sajnálatos módon az elkövetők nem válogatnak a sértettek között, az a gyermekkorúval kezdődően egészen az időskorúig megtalálható (gyermekkorú $1 \mathrm{db}$ vs. időskorú $1 \mathrm{db}$ ).

Következtetésként elmondható, hogy a nemzetközi és a hazai jogalkotás mindent megtett azért, hogy az emberi méltóságot és életet a kínvallatással szemben megvédje, mégis vannak olyanok, akik a hivatalos eljárásukban hivatalos személyként úgy próbálnak meg másokat vallomásra bírni vagy nyilatkoztatni, hogy ahhoz a kényszer és fenyegetés legkülönfélébb módozatait használják. Ahogy azt a történeti előzményben is olvashattuk, az ókori és középkori sötétség vakította inkvizíciós eljárásoknak nincs helyük a büntető igazságszolgáltatásban, amelynek garanciája egyrészt a büntetőjogban alkalmazott alapelvek, másrészt a nemzetközi jogban érvényesített klauzulák.

A hivatali eljárásoknak mindig jogszerünek, törvényszerűnek és szakszerűnek kell lenniük, csak ezáltal nő a közhivatalokba vetett társadalmi bizalom, és csak ezáltal vallhatunk olyan értékeket, amelyek a demokratikus társadalomban az emberi és alkotmányos alapjogokon nyugszanak. Mindezt a hivatali személyeknek a hivatali eljárásukban kétséget kizáróan alkalmazniuk kell.

\section{Irodalomjegyzék}

Bakonyi Mária: A beismerő vallomás fonákja és színe - a kényszertöl a konszenzusig. Doktori értekezés. Pécs, Pécsi Tudományegyetem Állam- és Jogtudományi Kar Doktori Iskola, 2019. Online: https://pea.lib.pte.hu/bitstream/handle/pea/23228/bakonyi-maria-phd-2019.pdf?sequence= 1\&isAllowed $=\mathrm{y}$

Belovics Ervin (szerk.): Büntetőjog V. Általános rész. Budapest, HVG-ORAC, 2014.

Beccaria, Cesare: Dei delitti e delle pene. Livorno, Marco Coltellini, 1764.

Beccaria, Cesare: Dei delitti e delle pene. Venezia, Bassano, 1797.

Beccaria, Cesare: Elementi di economia pubblica. Milano, Nella stamperia e fonderia di G.G. Destefanis, 1804.

Beccaria, Cesare: A bünökről és a büntetésekről. Ford. Madarász Imre. Budapest, Eötvös József, 1998.

Beccaria, Cesare: A bünökröl és a büntetésekröl. Ford. Madarász Imre. Budapest, ELTE Államés Jogtudományi Kar Demokratikus Diákuniója - Országos Pedagógiai Könyvtár és Múzeum, 1989.

Beccaria, Cesare: Büntett és büntetés. Ford. Sebestyén Pál és Kádár Miklós. Budapest, Akadémiai Kiadó, 1967.

Beccaria, Cesare: Büntett és büntetés. Ford. Tarnai János. Budapest, Révai Leo, 1887.

Compagnino, Gaetano: Gli illuministi italiani. Roma-Bari, Editori Laterza, 1982.

Diós István - Viczián János (szerk.): Magyar Katolikus Lexikon. Budapest, Szent István Társulat, 1993.

Filangieri, Gaetano: Scienza della Legislazione. Napoli, Nella Stamperia di Amato Cons, 1780.

Firpo, Luigi (szerk.): Edizione Nazionale delle Opere di Cesare Beccaria. Milano, Mediobanca, 1984.

Galiani, Ferdinando: Della Moneta. Napoli, Nella Stamperia Simoniana, 1751. 
Galicz Kamilla: A felvilágosodás elfeledett polihisztora: Pietro Verri. Studia Iuvenum Iusperitorum, (2018), 9. 43-57. Online: https://epa.oszk.hu/02500/02567/00009/pdf/EPA02567_studia_iuvenum_9_043-057.pdf

Genovesi, Antonio: Lezioni di commercio, o sia d'economia civile. Milano, Dalla Societa Tipografica de Classici Italiani, 1765.

Gyöngy Réka: A kényszervallatás tényállásának értelmezéséhez. Debreceni Jogi Mühely, 9. (2012), 3. 86-95. Online: https://doi.org/10.24169/DJM/2012/3/9

Hautzinger Zoltán: Prológus. Cesare Beccaria, a bűnmegelőzési tudomány történetének nagy gondolkodója. In Hautzinger Zoltán (szerk.): Tanulmányok a „Határőrség szerepe a bünmegelözésben" címü tudományos konferenciáról. Pécs, Magyar Hadtudományi Társaság, 2003. 7-9.

Lamm Vanda - Peschka Vilmos (föszerk.): Jogi Lexikon. Budapest, KJK-Kerszöv, 1999.

Maestro, Marcello: Cesare Beccaria e le Origini della Riforma Penale. Milano, Editori Feltrinelli, 1977. Márkus Dezső: Magyar Jogi Lexikon. Budapest, Pallas Irodalmi és Nyomdai Részvénytársaság, 1907. Mezey Barna: Kínzás, kínszenvedés, kivégzés. Rubicon, 17. (2006), 7. 14-36.

Mortier, Roland: Az európai felvilágosodás fényei és árnyai. Budapest, Gondolat, 1984.

Mucsi Emese: Egy könyv - kétszáz év távlatából. Világtörténet, 9. (1987), 1. 61-83. Online: http:// real-j.mtak.hu/2118/1/Vilagtortenet_1987.pdf

Nagy Sándor: Kínvallatás a hajdúvárosok és a hajdúkerületi törvényszék előtt indított bünügyekben. A Hajdú-Bihar Megyei Levéltár Évkönyve, (1997), 24. 25-56.

Papp Orsolya: Jogi- és közigazgatási ismeretek. II. Budapest, MRSZKI, 2016. Online: www.mrszg. hu/images/docs/rendeszetiagazati/mrszki_sa/btk_kul_2016_po.pdf

Stipta István: Cesare Beccaria Bủntett és büntetés című művének recepciója Magyarországon. Jogtörténeti Szemle, (2019), 3-4. 10-16.

Takács Andrea: Brian Innes: A kínzás és kínvallatás története - Könyvismertetés. Belügyi Szemle, 49. (2011), 11. 123-128.

UNHR: Convention against Torture and Other Cruel, Inhuman or Degrading Treatment or Punishment (1984. december 10.). Online: www.ohchr.org/en/professionalinterest/pages/cat.aspx

Venturi, Franco: Settecento riformatore I. Da Muratori a Beccaria. Torino, Einaudi, 1969.

Verri, Pietro: Meditazioni sull'Economia Politica. Milano, Nella stamperia e fonderia di G. G. Destefanis, 1771.

Verri, Pietro: Osservazioni sulla Tortura. Milano, Milano Presso de Giuseppe Marelli, 1777.

Voltaire, François-Marie Arouet: Prix de la Justice et de l'Humanité. Berne, Gazette de Berne, 1777.

Voltaire, François-Marie Arouet: Commentaire sur le livre des délits et des peines. Berne, Gazette de Berne, 1766.

Von Sonnenfels, Joseph: Ueber die Abschaffung der Tortur. Zürich, Orell, Gessner, Füessling und Company, 1775.

\section{Jogforrások}

2012. évi C. törvény a Büntető Törvénykönyvről Online: https://net.jogtar.hu/jogszabaly?docid= a1200100.tv

2017. évi XC. törvény a büntetőeljárásról. Online: https://net.jogtar.hu/jogszabaly?docid=a1700090.tv Magyarország Alaptörvénye (2011. április 25.) Online: https://net.jogtar.hu/jogszabaly?docid= a1100425.atv

United Nations: A Universal Declaration of Human Rights (1948. december 10.). Online: https:// undocs.org/A/RES/217(III) 